\title{
Chemistry and insecticidal potential of bay leaf essential oil against stored grain pest of wheat
}

\author{
K. K. Chahal*, Ritima Bansal and Ramandeep Kaur \\ Department of Chemistry, Punjab Agricultural University, Ludhiana-141004 (Punjab), INDIA \\ ${ }^{*}$ Corresponding author. E-mail: drkkchahal@pau.edu
}

Received: February 4, 2016; Revised received: July 1,2016; Accepted: November 6, 2016

\begin{abstract}
A laboratory experiment was conducted to study chemistry and insecticidal activity of bay leaf oil, its fractions and isolated compounds against stored grain pest of wheat i.e. Tribolium castaneum Herbst. Bay leaf essential oil extracted from dried and powdered bay leaves was subjected to column chromatography to have its fractions. Extensive column chromatography of polar fraction yielded Eugenol and 7, 7 Dimethyl-3-methylene bicyclo [2.2.1] heptan-4-ol which were identified by spectroscopic techniques. Bay leaf oil was tested for its insecticidal activity at five different concentrations in the range $4-12 \mathrm{mg} \mathrm{g}^{-1}$ respectively against $F_{1}$ generation of red rust flour beetle adults. Maximum inhibition was observed at $12 \mathrm{mg} \mathrm{g}^{-1}$ concentration. The activity was both time and concentration dependent.The fractions of bay leaf essential oil and the compounds isolated were tested at $4 \mathrm{mg} \mathrm{g}^{-1}$ concentration. Polar fraction was found to be more active as compared to nonpolar fraction as 100 and $53.1 \%$ mortality was obtained on $30^{\text {th }}$ day for polar and nonpolar fractions, respectively. Comparison of eugenol and 7, 7 Dimethyl-3-methylene bicyclo [2.2.1] heptan-4-ol showed complete mortality on $33^{\text {rd }}$ and $35^{\text {th }}$ day respectively, which revealed that adults of $T$. castaneum were more susceptible to eugenol. The results indicated that bay leaf essential oil may have potential to control stored grain pest, $T$. castaneum.
\end{abstract}

Keywords: Essential oil, Laurus nobilis, Stored grain pest, Tribolium castaneum

\section{INTRODUCTION}

Wheat is major food crop grown in Punjab. Substantial amount of wheat is stored in godowns by farmers, flourmills and government procurement agencies. Beetles are of great importance in grain storage systems as their activity on stored produce leads to losses both in quality and quantity. In India losses caused by deterioration under adverse storage conditions account for 6.5 percent of stored grains (Raju, 1984) and it ranged between 10-40\% worldwide (Raja et al., 2001). Indiscriminate use of large quantities of toxic and persistent pesticides (Agnihotri, 2000) can result in many problems in the biosphere leading to imbalance, damage to non-target organisms (Halder et al., 2010).The chemical residues in grains pose health hazards to the consumers as most of our flourmills grind wheat without washing. In India, cereal consumption is quite high as compared to western countries and therefore even small amount of insecticide residues left on grains will result in a large intake. It is therefore imperative to find out non-insecticide control measures. One such possibility is the use of essential oils as pest control measure as they are non-toxic, non-hazardous for mammals as well as environment (Credland, 1992; Zhang et al., 2000; Adedire and Akinkurolere, 2005) and at the same time have sufficient persistence for the control of pests. Essential oils being volatile are known to be effective against fungi (Stevic et al., 2014; Soylu et al., 2005), bacteria (Prabuseenivasan et al., 2006), virus (Patel et al., 2000) and insects (Geetha and Roy, 2014; Ayvaz et al., 2010). Dried bay leaf (L. nobilis), a spice used in traditional culinary practices as a flavouring agent could be used as botanical biopesticide in postharvest crop protection (Kivçak and Mert, 2002). In this context, Papachristos and Stamopoulos (2002) reported that bay leaf essential oil has a repellent action against the bean weevil Acanthoscelides obtectus (Say). Bay leaf essential oil obtained from Tunisia, Algeria and Morocco were reported to possess repellent and fumigant toxicity against stored grain pests (Jemma et al., 2012). Correspondingly, Cosimi et al. (2009) reported that the essential oilwas repellent to Sitophilus zeamais (Motschulsky), Cryptolestes ferrugineus (Stephens) and Tenebrio molitor (L.). Andronikashvili and Reichmuth (2002) and Rozman et al. (2007) reported the fumigant activity of naturally occurring compounds of this essential oil and some other plants against three stored productbeetles, $T$. castaneum, S. oryzae (L.) and R. dominica (F.). Besides various fumigant and repellent activities of bay leaf essential oil against stored grain pest (Cosimi et al., 2009; Lee et al., 2003), few reports are available on the insecticidal potential of bay leaf oil and its fractions against $T$. castaneum. So there exists tremendous scope for exploiting the activity of bay leaf essential 
oil against stored grain pest of wheat. In the present study, bay leaf oil, its fractions were evaluated against stored grain pest of wheat $T$. castaneum under laboratory conditions. Moreover the isolation of pure compounds from the most bioactive fraction and their activity against $T$. castaneum was also undertaken.

\section{MATERIALS AND METHODS}

Bay leaves were purchased from local market. The shade dried leaves were powdered and used for extraction of essential oil. The powdered leaves were taken in one litre flat-bottomed flask and $400 \mathrm{ml}$ of distilled water was added to it. The contents were thoroughly mixed and flask was kept overnight. The flask was placed on hot plate and fitted with reflux condenser attached to Dean and Stark water apparatus. The contents were refluxed on a hot plate at $100^{\circ} \mathrm{C}$ for about five hours. The oil extracted using hydrodistillation method. The essential oil layer containing little water was collected in a conical flask. The same procedure was repeated to process 13 batches. The essential oil layers were pooled in a conical flask and partitioned using diethyl ether $(3 \times 100 \mathrm{ml})$. The ether layer was dried over sodium sulfate and excess solvent was evaporated using vacuum and finally oil was stored in a stoppered tube. The bay leaf essential oil obtained was pale yellow liquid with sweet spicy clove like odour having $\mathrm{pH}$ and refractive index of 6.9 and 1.51 respectively. The essential oil was insoluble in water and soluble in alcohol, diethyl ether and glacial acetic acid.

Bay leaf essential oil (12.0 g) was subjected to column chromatography to fractionate it into hexane and dichloromethane to have non-polar and polar fractions respectively using silica gel (60-120 mesh) as an adsorbent. The polar fraction (4.0 g) of essential oil was chromatographed over a silica gel by gradient dilution with hexane, hexane-dichloromethane and then pure dichloromethane (Table 1). Fractions $(100 \mathrm{ml})$ were collected and concentrated over water bath, and similar fractions were combined according to thin layer chromatographic profiling. Two compounds eugenol and 7, 7 dimethyl-3methylene bicyclo [2.2.1] heptan-4-ol were isolated. The structural elucidation based on IR, ${ }^{1} \mathrm{HNMR}$ and ${ }^{13} \mathrm{CNMR}$ was carried out (Table 2). FT-IR spectra were measured in $\mathrm{CHCl}_{3}$ solution or nujol on a Perkin Elmer, Model RX-1 FT-IR spectrophotometer. ${ }^{1} \mathrm{HNMR}$ and ${ }^{13} \mathrm{CNMR}$ spectra were recorded with Bruker AC (400 MHz) or mentioned otherwise as solutions (in $\mathrm{CDCl}_{3}$ ) using TMS as an internal reference. FTIR, ${ }^{13} \mathrm{CNMR}$ and ${ }^{1} \mathrm{HNMR}$ spectroscopic analysis was taken at Central Instrumentation Laboratories (CIL), Panjab University, Chandigarh. The chemical shifts are expressed in $\delta$ (ppm) values and the abbreviationss, $\mathrm{d}$, $\mathrm{t}$ and $\mathrm{m}$ stand for singlet, doublet, triplet and multiplet respectively.

Insecticidal activity: The wheat grains were sterilized at $60 \pm 5^{\circ} \mathrm{C}$ for 8 hours in order to eliminate both appar- ent and hidden infestation of insects if any. These grains were conditioned at least for a week in an environmental chamber maintained at $30 \pm 2^{\circ} \mathrm{C}$ and 75 per cent relative humidity to raise their moisture content. The red flour beetle ( $T$. castaneum) was obtained from laboratory cultures maintained in the Department of Entomology, PAU Ludhiana, maintained at $28 \pm 1^{\circ} \mathrm{C}$ and $70 \%$ relative humidity. The insects were reared in glass containers containing wheat flour and yeast $(10: 1, w / w)$. From these jars adults of known age (1-2 weeks) i.e. $F_{1}$ generation was obtained for the experimental purpose. The insecticidal activity of bay leaf essential oil against $T$. castaneum adults was tested at five different concentrations ranging from 4-12 $\mathrm{mg} \mathrm{g}^{-1}$ (Table 3). Stock solutions were prepared. For the experiment, wheat $(20.0 \mathrm{~g})$ was spiked with different concentrations of the essential oil. The observations of mortality were taken after every $24 \mathrm{hrs}$ till complete or constant mortality was obtained. The percent mortality was calculated using Abbott's formula (Abbott, 1925). The statistical analysis was carried out to determine $\mathrm{LC}_{50}$ values of the bay leaf oil against $T$. castaneum adults (Table 4). Bay leaf essential oil was fractioned into non-polar and polar fractions respectively for insecticidal activity by column chromatography over silica gel (60-120 mesh size). The column chromatography of polar fraction of bay leaf essential gave two compounds eugenol (1) and 7, 7 dimethyl-3 methylene bicyclo [2.2.1] heptan-4-ol (2) which were characterized by spectral techniques and used for insecticidal activity at $4 \mathrm{mg} \mathrm{g}^{-1}$ (Table 2 ). There were three replications for each treatment and for control only wheat and acetone were used.

\section{RESULTS AND DISCUSSION}

Essential oil of was extracted from dried and powderedbay leaves by hydrodistillation method in 3.0 percent yield which was more as compared to the yields of hydrodistilled bay leaf oil obtained from $\mathrm{Tu}-$ nisia, Algeria and Morocco showing yields of $0.584 \%$, $0.46 \%$ and $0.655 \%$ respectively (Jemma, et al., 2012) The bay leaf essential oil was pale yellow liquid having clove oil like odour with $\mathrm{pH}$ and refractive index of 6.9 and 1.51 respectively. It was insoluble in water and soluble in alcohol, diethyl ether and acetic acid. Thin

Table 1. Column chromatography of the polar fraction to separate the mixture of compounds.

\begin{tabular}{llcc}
\hline S.N. & Solvent used & $\begin{array}{c}\text { Weight } \\
\mathbf{( g )}\end{array}$ & $\begin{array}{c}\text { TLC based } \\
\text { remarks }\end{array}$ \\
\hline 1. & Hexane $(5 \times 100 \mathrm{ml})$ & Traces & - \\
2. & $\begin{array}{l}\text { Hexane: Dichloromethane } \\
5 \%(10 \times 100 \mathrm{ml})\end{array}$ & 3.4 & $\begin{array}{c}\text { Pure compound(1), } \\
\text { liquid }\end{array}$ \\
& $\begin{array}{l}\text { Hexane: Dichloromethane } \\
\text { 3. }\end{array}$ & 0.007 & $\begin{array}{c}\text { Mixture } \\
5 \%(10 \times 100 \mathrm{ml})\end{array}$ \\
& $\begin{array}{l}\text { Hexane: Dichloromethane } \\
5 \%(8 \times 100 \mathrm{ml})\end{array}$ & 1.2 & $\begin{array}{c}\text { Pure compound }(2), \\
\text { solid }\end{array}$ \\
\hline
\end{tabular}


Table 2. Spectral data of the isolated compounds.

\begin{tabular}{|c|c|c|c|}
\hline Compound & IR $\left(\mathrm{cm}^{-1}\right)$ & $\begin{array}{l}{ }^{1} \text { HNMR } \\
(\delta \text { ppm })\end{array}$ & $\begin{array}{c}{ }^{13} \text { CNMR } \\
(\delta \text { ppm) }\end{array}$ \\
\hline & $\begin{array}{c}3514,3076,1638 \\
1610,1149,1112 \\
1034,995,794,746 .\end{array}$ & $\begin{array}{c}3.19 \text { and } 3.21\left(\mathrm{~d}, 2 \mathrm{H}, \mathrm{J}=6.7 \mathrm{~Hz}, \mathrm{C}_{7}-\mathrm{Hs}\right), \\
3.7\left(\mathrm{~s}, 3 \mathrm{H}, \mathrm{C}_{10^{-}} \mathrm{Hs}\right), 4.95\left(\mathrm{~m}, 2 \mathrm{H}, \mathrm{C}_{9^{-}}\right. \\
\mathrm{Hs}), 5.57(\mathrm{~s}, 1 \mathrm{H}, \mathrm{OH}), 5.84\left(\mathrm{~m}, 1 \mathrm{H}, \mathrm{C}_{8^{-}}\right. \\
\mathrm{H}), 6.56\left(\mathrm{~m}, 2 \mathrm{H}, \mathrm{C}_{5} \text { and } \mathrm{C}_{6}-\mathrm{Hs}\right), 6.73 \\
\left(\mathrm{~d}, 1 \mathrm{H}, \mathrm{J}=3.6 \mathrm{~Hz}, \mathrm{C}_{3}-\mathrm{H}\right)\end{array}$ & $\begin{aligned} & 39.83\left(\mathrm{C}_{7}\right), 5.56\left(\mathrm{C}_{10}\right), 111.10\left(\mathrm{C}_{3}\right), \\
& 114.29\left(\mathrm{C}_{6}\right), 115.45\left(\mathrm{C}_{9}\right), 121.11\left(\mathrm{C}_{5}\right), \\
& 131.85\left(\mathrm{C}_{4}\right), 137.81\left(\mathrm{C}_{8}\right), 143.83\left(\mathrm{C}_{1}\right), \\
& 146.43\left(\mathrm{C}_{2}\right)\end{aligned}$ \\
\hline & $\begin{array}{c}3376,3081,1635 \\
1455,1375,888\end{array}$ & $\begin{array}{c}0.97\left(\mathrm{~d}, 6 \mathrm{H}, \mathrm{J}=6.2 \mathrm{~Hz}, \mathrm{C}_{7} \text { and } \mathrm{C}_{9}-\mathrm{Hs}\right) \\
4.61\left(\mathrm{~d}, 2 \mathrm{H}, \mathrm{J}=10.2 \mathrm{~Hz}, \mathrm{C}_{10}-\mathrm{Hs}\right)\end{array}$ & $\begin{array}{c}24.8\left(\mathrm{C}_{6}\right), 26.1\left(\mathrm{C}_{8}\right)^{\mathrm{a}}, 26.7\left(\mathrm{C}_{9}\right)^{\mathrm{b}}, 29.9 \\
\left(\mathrm{C}_{2}\right), 38.9\left(\mathrm{C}_{5}\right), 41.8\left(\mathrm{C}_{1}\right), 53.4\left(\mathrm{C}_{7}\right), \\
82.6\left(\mathrm{C}_{4}\right), 106.3\left(\mathrm{C}_{10}\right), 153.5\left(\mathrm{C}_{3}\right),(\mathrm{a}) \\
\text { and }(\mathrm{b}) \text { are interchangeable. }\end{array}$ \\
\hline
\end{tabular}

Tabl 3. Corrected percent mortality of $T$. castaneum adults by bay leaf oil at indicated time intervals.

\begin{tabular}{|c|c|c|c|c|c|}
\hline \multirow{2}{*}{ No. of Days } & \multicolumn{5}{|c|}{ Concentration $\left(\mathrm{mg} \mathrm{g}^{-1}\right)$} \\
\hline & 12 & 10 & 8 & 6 & 4 \\
\hline 1 & 83.3 & 73.3 & 61.6 & 60.3 & 53.3 \\
\hline 2 & 88.3 & 76.6 & 73.3 & 73.3 & 60.0 \\
\hline 4 & 95.0 & 81.6 & 76.6 & 76.6 & 65.0 \\
\hline 5 & 100 & 81.6 & 77.5 & 77.5 & 65.0 \\
\hline 7 & - & 98.0 & 83.9 & 79.2 & 69.7 \\
\hline 8 & - & 100 & 83.9 & 79.2 & 69.7 \\
\hline 10 & - & - & 88.2 & 82.0 & 71.9 \\
\hline 11 & - & - & 100 & 88.6 & 71.9 \\
\hline 15 & - & - & - & 88.6 & 75.0 \\
\hline 27 & - & - & - & 91.6 & 81.2 \\
\hline 33 & - & - & - & 100 & 87.5 \\
\hline 37 & - & - & - & - & 100 \\
\hline
\end{tabular}

Table 4. Statistical analysis of bay leaf oil for toxicity studies.

\begin{tabular}{ccccc}
\hline S. & \multirow{2}{*}{ Time (hrs) } & \multirow{2}{*}{$\mathbf{L C}_{\mathbf{5 0}}\left(\mathbf{m g ~ g}^{\mathbf{1}}\right)$} & \multicolumn{2}{c}{ Heterogeneity } \\
\cline { 4 - 5 } N. & & 3.6 & $\mathbf{x}^{\mathbf{2}}$ & $\mathbf{d . f .}$ \\
\hline 1 & 24 & 2.7 & 2.13 & 3 \\
2 & 48 & 2.9 & 3.6 & 3 \\
3 & 72 & 2.7 & 5.44 & 3 \\
4 & 96 & 3.0 & 1.27 & 3 \\
5 & 120 &
\end{tabular}

Table 6. Comparison of percent mortality of $T$. castaneum using isolated pure compounds at indicated time intervals after treatment at $4 \mathrm{mg} \mathrm{g}^{-1}$.

\begin{tabular}{ccc}
\hline $\begin{array}{c}\text { No. of } \\
\text { Days }\end{array}$ & \multicolumn{2}{c}{ Corrected percent mortality } \\
\cline { 2 - 3 } & Eugenol & $\begin{array}{c}\mathbf{7 , 7} \text { dimethyl-3methylene } \\
\text { bicyclo[2.2.1]heptan-4-0l }\end{array}$ \\
\hline 1 & 50.0 & 47.5 \\
2 & 50.0 & 50.0 \\
7 & 60.0 & 52.5 \\
14 & 60.7 & 56.0 \\
20 & 64.1 & 59.8 \\
25 & 64.5 & 65.6 \\
28 & 79.1 & 78.1 \\
30 & 87.5 & 84.4 \\
32 & 95.8 & 90.6 \\
33 & 100 & 90.6 \\
34 & - & 93.8 \\
35 & - & 100 \\
\hline
\end{tabular}

Table 5. Comparison of corrected percent mortality of $T$. castaneum using non-polar and polar fractions of bay leaf oil at indicated time intervals after treatment at $4 \mathrm{mg} \mathrm{g}^{-1}$.

\begin{tabular}{ccc}
\hline \multirow{2}{*}{ No. of Days } & \multicolumn{2}{c}{ Corrected percent mortality } \\
\cline { 2 - 3 } & Non-polar fraction & Polar fraction \\
\hline 1 & 22.5 & 58.3 \\
2 & 22.5 & 60.0 \\
5 & 32.5 & 61.6 \\
10 & 38.4 & 62.0 \\
14 & 38.4 & 66.1 \\
25 & 40.6 & 83.3 \\
27 & 46.8 & 95.8 \\
29 & 50.0 & 97.8 \\
30 & 53.1 & 100 \\
\hline
\end{tabular}

layer chromatography of bay leaf essential oil showed three different colored spots having $\mathrm{R}_{\mathrm{f}}$ values of 0.41 , 0.59 and 0.76 when visualized by using sulfuric acid: methanol (9: 1) spray reagent.

Identification and characterization of pure compounds: Polar fraction upon column chromatography yielded two pure compounds eugenol (1) and 7, 7 dimethyl-3methylene bicyclo [2.2.1] heptan-4-ol(2). IR spectrum of compound (1) showed band at $3514 \mathrm{~cm}^{-1}$ indicating the presence of $-\mathrm{OH}$ group. The bands at 
3076, 1638 and $995 \mathrm{~cm}^{-1}$ were due to $-\mathrm{CH}_{2}$ (stretching), $\mathrm{C}=\mathrm{C}$ (stretching) and $-\mathrm{CH}_{2}$ (bending) respectively indicate the presence of vinyl group. Bands at 1610,794 and $746 \mathrm{~cm}^{-1}$ supported the presence of aromatic ring. Also the bands at 1149, 1122 and 1034 $\mathrm{cm}^{-1}$ were attributed to $-\mathrm{C}-\mathrm{O}$ stretching. ${ }^{1} \mathrm{H}$ NMR spectrum of compound showed a $3 \mathrm{H}$ singlet at $\delta 3.7$, which was typical of a methoxy group. The presence of two hydrogen atoms was confirmed by doublets at $\delta 3.21$ and $3.19(\mathrm{~J}=6.7 \mathrm{~Hz})$. A broad singlet due to hydroxyl group was obtained at $\delta 5.57$ that was exchangeable with deuterium $\left(\mathrm{D}_{2} \mathrm{O}\right)$ and hence may be attributed to hydroxyl group $(-\mathrm{OH})$ which was supported by IR spectrum. In addition to this a three hydrogen multiplet system typical of a vinyl group together with another multiplet for three hydrogen atoms in the aromatic ring suggests this compound to be aromatic system very near to eugenol. An INEPT study of the compound showed the presence of two methylenes. Spectral data together with biogenetic considerations showed the compound to be eugenol. A survey of literature confirmed this compound to be eugenol as it showed super imposable IR spectrum with that reported in the literature (Bhagat et al., 1982). This compound was also reported to be present in freshbay leaf extract (Killic et al., 2004).

The peculiar shape of band at $3376 \mathrm{~cm}^{-1}$ in IR spectrum of compound (2) suggested the presence of $-\mathrm{OH}$ group. Bands at $3081 \mathrm{~cm}^{-1}(\mathrm{C}-\mathrm{H}$ bending) indicated the presence of exo-methylene double bond. Presence of gem dimethyl group was also supported by band at $1375 \mathrm{~cm}^{-1}{ }^{1} \mathrm{H}$ NMR spectrum showed a doublet at $\delta$ $0.97(\mathrm{~J}=6.2 \mathrm{~Hz})$ arising due to presence of $6 \mathrm{H}$ indicating the presence of gem dimethyl group. A doublet was obtained at $\delta 4.61(\mathrm{~J}=10.2 \mathrm{~Hz})$ for the two $\mathrm{H}$ atoms indicated the presence of exomethylene double bond. Absence of signals in the region $\delta 3-4$ due to $\mathrm{H}-$ atom(s) present on $\mathrm{C}$ having $\mathrm{OH}$ group indicated the tertiary nature of hydroxyl group. All these data suggested structure (2) for this compound (7, 7 dimethyl-3 methylene bicyclo [2.2.1] heptan-4-ol). This structure was further confirmed by ${ }^{13} \mathrm{C}$ NMR spectral data. It showed the presence of two olefinic carbons at $\delta 153.5$ and 106.3 , while the signal at $\delta 82.6$ as singlet showed the presence of tertiary hydroxyl group. The data further supported structure (2) for this compound as it showed three methylenes $\delta(38.9,29.9$ and 24.8 as triplet), two methyl groups $\delta$ (26.7 and 26.1 as quintets), one methyne $\delta$ (47.8 as doublet) and two quaternary carbons $\delta$ (82.6 and 53.4 as singlets).

Insecticidal activity: Literature revealed that a variety of essential oils and their constituents possessed varying degrees of pest control properties. Their low mammalian toxicity and persistence in the environment made plant based volatile oils attractive candidates for the protection of stored food products against insect pests. Monoterpenoids are widely distributed in the essential oils of aromatic plants (Roger, 1999; Dahmane et al., 2016) and more than thousand different naturally occurring monoterpenoids were isolated from many higher plants including mint, pine, cedar, citrus and eucalyptus (Charlwood and Charlwood, 1991). Monoterpenes being lipophilic in nature may interfere with basic metabolite, biochemical, physiological and behavioral functions of insects (Brattsten, 1983).

The results pertaining to the treatment of bay leaf oil against $T$. castaneum are summarized in Table 3 . The perusal of Table showed 83.3, 73.3, 61.6, 60.3 and 53.3 per cent mortality at concentration of $12,10,8,6$ and $4 \mathrm{mg} \mathrm{g}^{-1}$ respectively one day after treatment. It showed more than 80 per cent mortality of adults at 12 $\mathrm{mg} \mathrm{ml} \mathrm{m}^{-1}$ after one day of exposure. After 2 days of treatment $88.3,76.6,73.3,73.3$ and 60.0 per cent mortality was observed at $12,10,8,6$ and $4 \mathrm{mg} \mathrm{g}^{-1}$ respectively. The data revealed that more than 70 per cent mortality was observed at all the four concentrations except at lowest concentration of $4 \mathrm{mg} \mathrm{g}^{-1}$. Ninety five per cent mortality was observed on fourth day of exposure at $12 \mathrm{mg} \mathrm{g}^{-1}$. Complete mortality was observed after 5 and 8 days of application at the rate of 12 and $10 \mathrm{mg} \mathrm{g}^{-1}$ respectively. The adult mortality of 83.9, 79.2 and 69.7 per cent was observed at treatments level of 8,6 and $4 \mathrm{mg} \mathrm{g}^{-1}$ respectively after 8 days of treatment. The data was in consonance with the earlier findings which showed that mortality increased with increase in concentration of lemongrass, eucalyptus, bottle brush and garlic oils (Chahal et al., 2004, 2005 and 2006). The $\mathrm{LC}_{50}$ values of bay leaf essential oil ranges between $2.7-3.6 \mathrm{mg} \mathrm{g}^{-1}$, showing it to be moderately effective against $T$. castaneum (Table 4). In order to study interactions between monoterpenoid and insects pests attempts have been made to isolate pure compounds from these essential oils and evaluate their bio efficacy against $T$. castaneum.

The perusal of Table 5 indicates that at $4 \mathrm{mg} \mathrm{g}^{-1}$ concentration the non polar and polar fractions of bay leaf oil showed 22.5 and 58.3 percent kill respectively after $24 \mathrm{hrs}$ of exposure period. More than 50 percent insect mortality was observed in case of polar fraction. The nonpolar fraction showed $32.5,38.4,38.4,40.6,46.8$, 50.0 and 53.1 percent mortality after $5,10,14,25,27,29$ and 30 days of application. However the polar fraction showed 61.6,62.0, 66.1,83.3,95.8 and 97.8 percent mortality at the end of 5,10,14,25,27 and 29 days of treatment respectively. The complete mortality was observed after 30 days of treatment in case of polar fraction whereas 53.1 percent mortality was observed on same day with non polar fraction and it remained constant upto 45 days after application. It was also observed that rate of mortality of adult insect in nonpolar fraction was less than the polar fraction. Moreover the percent mortality in case nonpolar fraction remained constant after 30 days of exposure period showing that nonpolar fraction of oil was not exerting 
any further toxic action on the insects. The difference in percent morality between two fractions may be due to different toxic effect of compounds present in these two fractions. The above data revealed that polar fraction was more toxic than nonpolar fraction. These results were contradictory with the earlier findings which showed the non-polar fractions to be more bioactive as compared to polar fraction (Chahal et al., 2014; Sharma and Chahal, 2012; Ray et al., 2010; Sharma et al., 2007). The difference may be due to presence of more bioactive compounds in polar fraction than nonpolar fraction.

In order toexplore the potential of bioactive compounds present in the bay leaf oil, two major compounds eugenol (1) and 7, 7 dimethyl-3methylene bicyclo [2.2.1] heptan-4-ol (2) isolated from polar fractionwere tested for their insecticidal activity against $T$. castaneum. The perusal of the Table 6 depicted the influence of both compounds on mortality rate of adults of test insect. After $24 \mathrm{hrs}$ of exposure 50.0 and 47.5 per cent adult mortality was observed in case of compound (1) and (2) respectively. Eugenol (1) showed $60.0,60.7$ and 64.5 percent kill whereas compound (2) showed 52.5, 56.0 and 65.6 percent mortality at the end of 7,14 and 25 days of treatment respectively which revealed that both the compounds were equally toxic towards stored grain pest. After 28 days of exposure more than 78 percent adult mortality was observed for both the compounds tested. After 30 days of treatment 87.5 (1) and 84.2(2) percent mortality was attained. Complete mortality for compounds (1) and (2) was observed after 33 and 35 days of treatment. Although there was increase in percent mortality with increase in exposure period but percent kill was more by compound (1) than compound (2).Thus eugenol was more active as insecticide than 7,7 dimethyl-3 methylene bicyclo [2.2.1] heptan-4-ol. This data was in agreement with findings of Obeng and Reichmuth (2010) who investigated the toxicity and protectant potential of eugenol(1) against Sitophillus granarius, S. zeamis, $T$. castaneum and Prostephanus truncates. Eugenol applied topically, impregnated on filter papers was highly toxic to all four species. Beetle mortality was dose dependent. Eugenol was highly repellant to the four beetle species tested with overall repellency in the range of $80-100$ percent. Development of eggs and immature stages inside grain kernels was completely inhibited by eugenol treatment. In an another study, Huang et al. (2002) reported the toxic effect of eugenol(1) against the adults of $S$. zeamais and T. castaneum, eugenol (1) that significantly reduced the food consumption in case of $T$. castaneum in flour disc bioassay with no choice test.

\section{Conclusion}

The present study revealed that the polar fraction of bay leaf essential oil was found to be most effective as compared to its fractions and compounds tested. The essential oil at 10 and $12 \mathrm{mg} \mathrm{ml}^{-1}$ was found to be effective in controlling infestation. The more toxic effect of polar fraction could be due to synergistic effect of the compounds present in it. Therefore plant oils may be the best alternative of insecticides because these are safe to environment and human beings.

\section{REFERENCES}

Abbott, W.S. (1925). A method of computing the effectiveness of an insecticide. Journal of Economic Entomolo$g y, 18: 265-267$

Adedire, C.O. and Akinkurolere, R.O. (2005). Bioactivity of four plant extracts on coleopterous pests of stored cereals and grain legumes in Nigeria. Zoological Research, 26:243-249

Agnihotri, N.P. (2000). Pesticides consumption in agriculture in India-An update. Pesticide Research Journal, 12:150 $-155$

Andronikashvili, M. and Reichmuth, C. (2002). Repellency and toxicity of essential oils from Ocimum gratissimum (Lamiaceae) and Laurus nobilis (Lauraceae) from Georgia against the rust-red flour beetle Tribolium castaneum (Herbst) (Coleoptera: Tenebrionidae). In: Credland, P.F., Armitage, D.M., Bell, C.H., Cogan, P.M., Highley, E. (Eds.), Advances in Stored Products Protection, Proc $8^{\text {th }}$ International Working Conference of Stored Product Protection, 22-26 July 2002, York. UK. CAB International, Wallingford, Oxon, pp. 749-762

Ayvaz, A., Sagdic, O., Karaborklu, S. and Ozturk, I. (2010) Insecticidal activity of the essentialoils from different plants against three stored product insects. Journal of Insect Science, 10:1-13

Bhagat, S.D. ,Mathur, R.K. and Siddhanta, N.N. (1982). Synthesis of new derivatives of eugenol and isoeugenol. Journal of Chemical and Engineering Data, 27:209210

Brattsten, L.B. (1983). Cytochrome P-450 involvement in the interaction between plant terpenesandinsect herbivores. In: Hedin P A (ed) Plant Resistance to Insects. American Chemical Society, Washington, pp. 173-195

Chahal K.K., Sandhu A.K. and Kang, B.K. (2014). Vetiver oil and its fractions as stored grain protectants. Pesticide Research Journal, 26:206-211

Chahal K.K., Arora, M., Joia, B.S. and Chhabra, B.R. (2006). Chemistry and potential of garlic oil against Tribolium castaneum as stored grain protectant. Proc $9{ }^{\text {th }}$ Punjab Science Congress. Guru Nanak Dev DentalCollege and Research Institute, Sunam. pp. 17

Chahal K.K., Kumari, M., Joia, B.S. and Chhabra, B.R. (2004). Bioefficacay of lemongrass oil Cymbopogon citratus against Tribolium castaneum under laboratory conditions. Proc $7^{\text {th }}$ Punjab Science Congress. Guru Nanak Dev University, Amritsar.pp. 18

Chahal, K.K, Kumari, M., Joia, B.S. and Chhabra B.R. (2005). Bioefficacy of essential oils against Tribolium castaneum under laboratory conditions Proc $8^{\text {th }}$ Punjab Science Cogress. Punjabi University, Patiala.pp.18

Chralwood, B.V. and Charlwood, K.A. (1991). Monoterpenoids. In: Charlwood, B.V. and Banthrope, D.V. (eds) Methods in Plant Biochemistry. Academic Press, London, pp. 43-98

Cosimi, S., Rossi, E., Cioni, P.L. and Canale, A. (2009). 
Bioactivity and qualitative analysis of some essential oils from Mediterranean plants against stored-product pests: Evaluation of repellency against Sitophilus zeamais Motschulsky, Cryptolestes ferrugineus (Stephens) and Tenebrio molitor (L.). Journal of Stored Product Research, 45:125-132

Credland, P.F. (1992). The structure of bruchid eggs may explain the ovicidal effect of oils. Journal of Stored Product Research, 28: 1-9

Dahmane, D., Dob, T. and Chelghoum, C. (2016). Essential oil composition and enatiomeric distribution of some monoterpenoid components of Juniperus communis L. from Algeria. Journal of Essential Oil Research, 28 (4):348-356

Geetha, R.V. and Roy, A. (2014). Essential oil repellents:A short review. International Journal of Drug Development and Research, 6:20-27

Halder, J., Srivastava, C. and Dureja, P. (2010). Effect of methanolic extracts of prewinkle (Vinca rosea) and bottlebrush (Callistemon lanceolatus) alone and their mixtures against neonate larvae of gram pod borer (Helicoverpa armigera). Indian Journal of Agricultural Sciences, 80:820-823

Huang, Y., Ho, S.H., Lee, H.C. and Yap, Y.L. (2002) Insectcidal properties of eugenol,isoeugenol and methyleugenol and their effects on nutrition of Sitophillus zeamais Motsch. (Coleoptera:Curculionidae) and $T$. castaneum (Herbst) (Coleoptera:Tenebrionidae). Journal of Stored Product Research, 38:403-412

Jemma, J.M.B., Tersim, N., Toudert, K.T. and Khouja, M.L. (2012). Insecticidal activities of essential oils from leaves of Laurus nobilis L. from Tunisia, Algeria and Morocco and comparative chemical composition. Journal of Stored Product Research, 48:97-104

Killic, A., Hafizoglu, H., Kollmannsberger and Nitz, S. (2004). Volatile constituents and key odorants in leaves, buds flowers and fruits of Laurus nobilis L. Journal of Agricultural and Food Chemistry, 52:1601-1606

Kivçak, B. and Mert, T. (2002). Preliminary evaluation of cytotoxic properties of Laurus nobilis leaf extracts. Fitoterapia, 73:242-243

Lee ,S., Peterson, C.J. and Coats, J.R. (2003). Fumigation toxicity of monoterpenoids to several stored product insects. Journal of Stored Product Research, 39: 77-85

Obeng, O.D. and Reichmuth, C.H. (2010). Bioactivity of eugenol, a major component of essential oil of Ocimum suave (wild) against four species of stored product Coleoptera. International Journal of Pest Management, 43:89-94
Papachristos, D.P. and Stamopoulos, D.C. (2002). Repellent, toxic and reproduction inhibitory effect of essential oil vapours on Acanthoscelides obtectus (Say) (Coleoptera: Bruchidae). Journal of Stored Product Research 38:117-128

Patel, K.D., Patel, P.M. and Patel, B.N. (2000). Inhibition of Tobacco virus infection by some plant extracts. Journal of Mycology and Plant Pathology, 30: 229-230

Prabuseenivasan, S., Jayakumar, M. and Ignacimuthu, S. (2006). In vitro antibacterial activity of some plant essential oils. BMC Complemetary and Aletrnative Medicine, 6:39-46

Raja , N.S., Albert, S., Ignacimuthu, S. and Dorn, S. (2001) Effect of plant volatile oils in stored cow pea Vigna unguiculata L. (Walpers) against Callosobruchus maculates (F.) (Coleopteran:Bruchidae) infestation. Journal of Stored Product Research, 37: 127-132

Raju, P. (1984). The straggering storage losses-causes and extent. Pesticides, 18:35-37

Ray, D.P., Srivastava, S. and Singh, R.P. (2010). Phytochemical screening and biological activity of marigold (Tagetes erecta L.) flower. Pesticide Research Journal, 22:1-4

Roger, C.R. and Hamraoui, A. (1999). Diversification of plant protection strategies. Use of monoterpenes. Acta Botanica Gallica, 14:35-41

Rozman, V., Kalinovic, I. and Korunic, Z. (2007). Toxicity of naturally occurring compounds of Lamiaceae and Lauraceae to three stored-product insects. Journal of Stored Product Research, 43:349-355

Sharma, N. and Chahal, K.K. (2012). Protectant potential of marigold oil (Tagetes erecta L.) and its fractions against Tribolium castaneum (Herbst.). Annals of Plant Protection Sciences, 20:294-297

Sharma, S., Singh, K. and Rani, M. (2007). Effects of Cedrus deodara and Tagetes erecta oil against Lipaphis erysimi. Annals of Plant Protection Sciences, 15: 472-474

Soylu, E.M., Tok, F.M., Soylu, S., Kaya, A.D. and Gulsun, A.E. (2005). Antifungal activities of essential oils on postharvest disease agent Penicillium digitatum. Pakistan Journal of Biological Sciences, 8:25-29

Stevic, T., Beric, T., Savikin, K., Sokovic, M., Godevac, D. and Dimikic, I. and Stankovic, S. (2014) Antifungal activity of selected essential oils against fungi isolated from medicinal plants. Industrial Crops and Products, 55:116-122

Zhang, H.Y., Ziniu, Y. and Wang, X.D. (2000). Isolation, distribution and toxicity of Bacillus thuringiensis from ware houses in China. Crop. Protection, 19:449-454 